\title{
Effect of Postpartum Pelvic Floor Muscles Training in Pelvic Floor Muscles Strength on Postpartum Women with Stress Urinary Incontinence
}

\author{
Pengaruh Latihan Otot Dasar Panggul terhadap Kekuatan Otot Panggul \\ pada Perempuan Postpartum dengan Stres Inkontinensia Urin \\ Jerisatrio S Tarukallo, David Lotisna, Nugraha U Pelupessy \\ Department of Obstetrics and Gynecology \\ Faculty of Medicine Universitas Hasanuddin/ \\ Dr. Wahidin Sudirohusodo Hospital \\ Makassar
}

\begin{abstract}
Objective: To evaluate the effect of pelvic floor training (Kegel exercise) on pelvic floor muscle strength in postpartum women with SUI.

Methods: Thirty-five birth vaginally postpartum women with SUI were experimentally enrolled. After four weeks of postpartum observation, the diagnosis of SUI confirmed, and all of these women were asked to complete the International Consultation on Incontinence Questionnaire-Sort Form (ICIQ-SF) questionnaire. The strength of the pelvic floor muscle measured with perineometer every once in 3 weeks for 12 weeks of Kegel exercise. SUI severity assessed with ICIQ-SF after completing the Kegel exercise. A paired t-test was used to compare measurement results between ICIQ-SF questionnaire and perineometer and multiple linear regression models was used for multivariate analysis. A p value of less than 0.05 was taken to be statistically significant.
\end{abstract}

Results: Findings show a significant difference between clinical variables (parity, neonates birth weight, perineal tear grade, BMI) and the improvement of pelvic floor muscles before and after performed the Kegel exercise (all $\mathrm{p}<0.05$ ). The pelvic floor muscles strength significantly improved $(p=0.000)$ after Kege exercise both in ICIQ-SF questionnaire and perineometer measurement.

Conclusion: Pelvic muscles floor training or Kegel exercise improve pelvic muscles floor strength in postpartum women with SUI.

[Indones J Obstet Gynecol 2018; 6-2: 114-118]

Keywords: pelvic muscles floor training, postpartum, stress urinary incontinence

\begin{abstract}
Abstrak
Tujuan: Untuk mengevaluasi efek latihan dasar panggul (latihan kegel) pada kekuatan otot dasar panggul pada wanita pascamelahirkan dengan SUI.

Metode: Tiga puluh lima perempuan postpartum dengan SUI dilibatkan dalam penelitian ini. Setelah 4 minggu observasi postpartum, diagnosis SUI dikonfirmasi dan semua partisipan diminta untuk melengkapi kuesioner the International Consultation on Incontinence Questionnaire-Sort Form (ICIQSF). Kekuatan otot lantai panggul diukur dengan perineometer setiap sekali dalam 3 minggu selama 12 minggu setelah latihan Kegel. Tingkat keparahan SUI dinilai dengan ICIQ-SF setelah latihan Kegel. Uji t berpasangan untuk membandingkan hasil pengukuran antara kuesioner ICIQ-SF dan perineometer dan model regresi linier berganda digunakan untuk analisis multivariat dengan tingkat kebermaknaan $p<0,05$.
\end{abstract}

Hasil: Hasil menunjukkan perbedaan signifikan antara variabel klinis (paritas, berat bayi lahir, derajat ruptur perineum, IMT) dan peningkatan kekuatan otot dasar panggul sebelum dan sesudah latihan Kegel (semua $p<0,05)$. Kekuatan otot dasar panggul meningkat secara signifikan $(p=0,000)$ setelah latihan Kegel baik pengukuran dengan kuesioner ICIQ-SF maupun perineometer.

Kesimpulan: Latihan otot dasar panggul atau latihan Kegel meningkatkan kekuatan otot dasar panggul pada perempuan postpartum dengan SUI.

[Maj Obstet Ginekol Indones 2018; 6-2: 114-118]

Kata kunci: latihan otot dasar panggul, postpartum, stres inkontinensia urin

\section{INTRODUCTION}

Stress urinary incontinence (SUI) is defined as the involuntary loss of urine on effort or physical exertion, or on sneezing or coughing ${ }^{1}$ results from either hypermobility of the vesicourethral segment due to weakness of the pelvic floor support or from intrinsic sphincter deficiency (ISD). ${ }^{2}$ ISD is due to lack of coaptation of the urethral wall and is diagnosed when a well-supported or non-mobile urethra leaks urine in response to a slight increase in intra-abdominal pressure in the absence of detrusor contraction. ${ }^{2}$ SUI often can occur during pregnancy and immediately after delivery (temporary or permanent basis) and this may be in addition to the risk of subsequently developing SUI in a woman's lifetime ${ }^{3}$ and contribute to the psychosocial impact in a woman's life in physical activity, travel, social relationships, and emotional health. ${ }^{4}$ 
The prevalence of persistent SUI varies from $18 \%$ to $50 \% .^{5-8}$ A systematic review of 33 population-based studies on the prevalence of postpartum urinary incontinence found that the pooled prevalence of any postpartum incontinence was 33\% in all women during the first 3 months postpartum. ${ }^{9}$ Age, obesity, diabetes, pelvic floor surgery, pregnancy, and delivery are the risk factors for the development of stress urinary incontinence in women ${ }^{10}$ which a significant percentage of women have persistent symptoms in the postpartum period. Prenatal incontinence increases the risk of postpartum incontinence, ${ }^{11}$ which in turn increases the risk of long-term persistent incontinence. ${ }^{12}$ The antenatal development of stress incontinence leads to an 18-times higher risk of developing stress incontinence after delivery, and the most prevalent group is delivered vaginally. ${ }^{13}$

The function of the pelvic floor muscles is to lend structural support to the pelvic structures, the urethra, vagina, and rectum. ${ }^{14}$ The strengthening of pelvic floor muscles is one of the first recommendations for the treatment of mild and moderate SUI. ${ }^{15}$ Conservative management of stress urinary incontinence often involves pelvic floor training. Pelvic muscle floor training (also known as Kegel exercise) involve the voluntary contraction of the levator ani (pelvic floor) muscles to increase their tone, strength, and endurance. ${ }^{16}$ Pelvic floor muscle training is one of the modalities for this treatment. ${ }^{10}$ This training has no significant side effects and enables improvement in SUI symptoms, and if the outcome is unsatisfactory, the patient can be referred for further evaluation and possible surgical intervention. ${ }^{17}$ Training of pelvic floor muscles during SUI has reached success rates of $56 \%$ to $75 \%{ }^{18}$

The assessment of muscular strength and endurance in postpartum women provides information about the severity of muscle weakness and is the basis for the planning of exercise programs for strengthening of pelvic floor muscles. The primary objective of this study was to evaluate whether the effect of pelvic floor exercises on pelvic floor muscle strength could be improved in stress urinary incontinence postpartum women and the secondary objective was to identify factors involved in stress urinary incontinence with postpartum women.

\section{METHODS}

Birth vaginally postpartum women with stress urinary incontinence were experimentally enrolled and underwent pelvic floor muscle training (Kegel exercise) in the present study at RSKDIA Siti Fatimah Makassar between December 2015 and June 2016. Postpartum women who reported with chronic diseases (hypertension, diabetes mellitus, chronic lung disease), perineal tear grade III-IV, cesarean delivery, postpartum of preterm birth, and complicated pregnancy or delivery were excluded from the study. All of the women who enrolled were fully informed about the study and gave their consent before enrollment. The study was approved by the Health Research Ethics Committee of Faculty of Medicine, Universitas Hasanuddin.

After 4 weeks of postpartum observation, the diagnosis of SUI confirmed and all of these women were asked to complete the International Consultation on Incontinence Questionnaire-Sort Form (ICIQ-SF) questionnaire. The strength of the pelvic floor muscle measured with perineometer (PFX09122, Laborie, Canada) every once in 3 weeks for 12 weeks of Kegel exercise. The severity of SUI assessed with ICIQ-SF after completing the Kegel exercise. A paired t-test was used to compare measurement results between ICIQ-SF questionnaire and perineometer. Multiple linear regression model was used for multivariate analysis. A p value less than 0.05 was considered to be statistically significant.

\section{RESULTS}

Thirty-five postpartum women with stress urinary incontinence were included in this study. Majority of these women were aged 20-30 years (48.6\%), multipara $(71.4 \%)$, neonates birth weight 3000 4000 gram $(77.1 \%)$, perineal tear grade $2(74.2 \%)$ and normal body mass index (BMI) (77.1\%). The baseline characteristics of the women are summarized in Table 1.

Table 1. Baseline Characteristics

\begin{tabular}{lcc}
\hline \hline \multicolumn{1}{c}{ Characteristics $(\mathbf{n = 3 5 )}$} & n & \% \\
\hline Age (years) & & \\
$<20$ & 11 & 31.4 \\
$20-30$ & 17 & 48.6 \\
$>30$ & 7 & 20
\end{tabular}




\section{Parity}

Primipara

Multipara

\section{0}

28.6

Neonates birth weight (gram)

$<3000$ gram

3000 - 4000 gram

Perineal tear grade

0

1

2

BMI $\left(\mathrm{kg} / \mathrm{m}^{2}\right)$

$<18$

$18-24.9$

$\geq 25.0$

In Table 2, the present study also shows a significant difference between clinical variables (parity, neonates birth weight, perineal tear grade, BMI) and the improvement of pelvic floor muscles before and after the women performed the Kegel exercise (all $\mathrm{p}<0.05)$. Based on measurement methods, the pelvic floor muscles significantly improved $(\mathrm{p}=0.000)$ after Kegel exercise both in ICIQ-SF questionnaire and perineometer measurement (Table 3). A multiple logistic regression models to identify the factors involved in the pelvic floor muscles strength for Kegel exercise show none of the factors (parity, neonates birth weight, perineal tear grade, BMI) significantly affect the pelvic floor strength (Table 4).

Table 3. Comparison between ICIQ-SF and Perineometer Measurement

\begin{tabular}{llll}
\hline \hline Measurement & before & after & p value \\
\hline ICIQ-SF score & $12.97 \pm 2.75$ & $9.03 \pm 3.25$ & 0.000 \\
Perineometer & $4.23 \pm 1.19$ & $6.34 \pm 1.71$ & 0.000 \\
\hline \hline
\end{tabular}

\section{DISCUSSION}

The present study found that pelvic floor muscles training increased pelvic floor muscles strength based on the results of perineometer and ICIQ-SF questionnaire. Perineometer measurements of pelvic floor muscle contractions show very good inter- and intrarater reliability compared to the

Table 2. Comparison of Pelvic Muscle Strength with Perineometer Measurement before and after Kegel Exercise

\begin{tabular}{|c|c|c|c|}
\hline Variables $(n=35)$ & before & after & p value \\
\hline \multicolumn{4}{|l|}{ Parity } \\
\hline Primipara & $4.80 \pm 1.03$ & $6.50 \pm 1.72$ & 0.008 \\
\hline Multipara & $4.00 \pm 1.19$ & $6.28 \pm 1.74$ & 0.000 \\
\hline \multicolumn{4}{|c|}{ Neonates birth weight (gram) } \\
\hline$<3000$ & $4.63 \pm 1.19$ & $7.13 \pm 1.89$ & 0.002 \\
\hline $3000-4000$ & $4.11 \pm 1.19$ & $6.11 \pm 1.63$ & 0.000 \\
\hline \multicolumn{4}{|l|}{ Perineal tear grade } \\
\hline 0 & $3.00 \pm 0.00$ & $5.00 \pm 0.00$ & - \\
\hline 1 & $4.00 \pm 1.69$ & $6.50 \pm 1.85$ & 0.003 \\
\hline 2 & $4.35 \pm 1.02$ & $6.35 \pm 1.72$ & 0.000 \\
\hline \multicolumn{4}{|l|}{ BMI $\left(\mathrm{kg} / \mathrm{m}^{2}\right)$} \\
\hline$<18.5$ & $5.00 \pm 1.41$ & $6.00 \pm 2.83$ & 0.5 \\
\hline $18.5-24.9$ & $4.22 \pm 1.22$ & $6.33 \pm 1.73$ & 0.000 \\
\hline$\geq 25$ & $4.00 \pm 1.10$ & $6.50 \pm 1.64$ & 0.010 \\
\hline
\end{tabular}

Table 4. Multivariate analysis Results to Identify Variables Associated with Pelvic Floor Muscle Strength

\begin{tabular}{lccccc}
\hline \hline & \multicolumn{2}{c}{$\begin{array}{c}\text { Unstandardized } \\
\text { Coefficients }\end{array}$} & $\begin{array}{c}\text { Standardized } \\
\text { Coefficients }\end{array}$ & t & Sig. \\
\cline { 2 - 4 } & B & Std Error & Beta & & \\
\hline Age & -0.061 & 0.046 & -0.31 & -1.333 & 0.193 \\
Parity & -0.299 & 0.234 & -0.303 & -1.276 & 0.212 \\
Birth weight & -0.001 & 0.001 & -0.173 & -1.034 & 0.31 \\
Perineal tear grade & -0.124 & 0.387 & -0.054 & -0.321 & 0.751 \\
BMI & 0.015 & 0.066 & 0.035 & 0.222 & 0.826 \\
\hline \hline
\end{tabular}


Brink total and pressure scores. ${ }^{19}$ Previous studies has reported the successful of pelvic floor muscles training for postpartum pelvic floor muscles strength and improvement in SUI. Pelvic floor muscles training is applied in 12- to 14-weeks and 6-months programs. A significant increase in pelvic floor muscles strength has been observed after 12-week programs. ${ }^{20}$ Pelvic floor muscles strength was significantly higher in women with PFME at gestational age 36 weeks and 3 months after delivery than control. ${ }^{21}$ Another study by Sampselle et al. suggested that pelvic floor muscles training can reduce the incidence of SUI at gestational ages of 35 weeks and at 6 weeks and 6 months postpartum by significantly increasing pelvic floor muscles strength compared with women who did not perform the training. ${ }^{22}$

Hormonal and metabolic changes associated with pregnancy and spontaneous healing of traumatic lesions due to vaginal childbirth might improve the postnatal of SUI. This is due to pelvic floor muscles play a urethral support role, and it may be aided by pelvic floor training. ${ }^{23}$ Improvement in pelvic floor muscles strength in women during the postpartum period showed that pregnancy, with its hormonal and mechanic effects, is a very important risk factor for UI during pregnancy. ${ }^{24}$

Pregnancy is one of the main risk factors for the development of SUI in young women. ${ }^{25}$ Studies in pregnant women with SUI have found significantly decreased pelvic floor muscles strength in incontinent pregnant women compared with continent pregnant women. ${ }^{26}$ Young-aged postpartum women with SUI mainly caused by stretching, pressure and ischemic to the endopelvic fascia, levator ani muscles and nerves in the pelvic floor. ${ }^{27}$ Keane et al. showed that the etiology of SUI in these pregnant women appears due to both quantitative and qualitative reduction in collagen. ${ }^{28}$

SUI risk also increased with parity or vaginal birth mode. ${ }^{29}$ Multigravidity causes a decrease in PFM strength at a rate of $22-35 \%$ beginning at a gestational age of 20 weeks and lasting until 6 weeks postpartum. ${ }^{30}$ Vaginal birth caused injury in levator ani and perineal nerves damage. ${ }^{31}$ Most cases of incontinence after vaginal birth occur as the results of injury to the muscles of the pelvic floor and its inervasion lead to neuropathy in $42 \%$ of postpartum women particularly in multiparous women and the second stage of labor extension.
Two months after vaginal delivery, the recovery of the pudendal nerve function approximately $60 \%$ of women, but others not. Nerve damage due vaginal delivery caused by a combination of strain and compression of the fetal head into the birth canal. ${ }^{32}$ The enlargement of the uterus and increase in fetal weight with gestational age, especially at the thirdtrimester influence the incontinence mechanism. Both factors have direct pressure on the bladder that might lead to changing the bladder-neck position $^{33}$ and reducing bladder capacity, contributing to bladder pressure that exceeds urethral pressure $^{34}$ and results in urine leakage. Excess body weight, as well as birth weight, also increases abdominal pressure, which in turn increases bladder pressure and urethral mobility, leading to stress UI and also exacerbating detrusor instability and overactive bladder. Like pregnancy, obesity may cause chronic strain, stretching and weakening the muscles, nerves and other pelvic floor structure. ${ }^{35}$ Degree of perineal tear either spontaneously or with episiotomy hypothesized have an influence on the pelvic floor dysfunction. Study found there was no difference in the urinary incontinence rate between episiotomy and spontaneous tears. ${ }^{36}$

Pelvic floor muscles training is the most commonly recommended conservative therapy for pregnant women with SUI. For women who are continent during pregnancy, this training may prevent urinary incontinence up to 6 months after delivery ${ }^{37}$ and recommend in first-line conservative management programmes for women with stress, urge, or mixed, urinary incontinence. ${ }^{38}$ Pelvic floor muscles training is more an effective treatment for SUI during pregnancy because it is a safe treatment without complications, inexpensive, simple to perform, does not require instruments, and can be done anywhere and anytime. ${ }^{17}$

\section{CONCLUSION}

Our study suggests pelvic muscles floor training or Kegel excersice improve pelvic muscles floor strength in postpartum women with SUI. Parity, neonates birth weight, perineal tear grade, and BMI contributed as risk factors in the present study.

\section{REFERENCES}

1. Haylen BT, de Ridder D, Freeman RM, et al., International Urogynecological Association; International Continence Society. An International Urogynecological Association 
(IUGA)/International Continence Society (ICS) joint report on the terminology for female pelvic floor dysfunction. Neurourol Urodyn 2010; 29: 4-20.

2. Sassani P, Aboseif SR. Stress Urinary Incontinence in Women. Curr Urol Rep. 2009; 10(5): 333-7.

3. Reynolds WS, Dmochowski RR, Penson DF. Epidemiology of stress urinary incontinence in women. Curr Urol Rep. 2011; 12(5): 370-6.

4. Sinclair AJ, Ramsay IN. The psychosocial impact of urinary incontinence in women. Obstet Gynecol. 2011; 13: 143-8.

5. Dooley Y, Kenton K, Cao G, et al. Urinary incontinence prevalence: results from the National Health and Nutrition Examination Survey. J Urol. 2008; 179(2): 656-61.

6. Azuma R, Murakami K, Iwamoto M, et al. Prevalence and risk factors of urinary incontinence and its influence on the quality of life of Japanese women. Nurs Health Sci. 2008; 10(2): 151-8.

7. Lee KS, Sung HH, Na S, Choo MS. Prevalence of urinary incontinence in Korean women: results of a National Health Interview Survey. World J Urol. 2008; 26(2): 179-85.

8. Onur R, Deveci SE, Rahman S, et al. Prevalence and risk factors of female urinary incontinence in eastern Turkey. Int J Urol. 2009; 16(6): 566-9.

9. Thom DE, Rortveit G. Prevalence of postpartum urinary incontinence: a systematic review. Acta Obstet Gynecol. 2010; 89: 1511-22.

10. Stothers L, Friedman B. Risk factors for the development of stress urinary incontinence in women. Curr Urol Rep. 2011; 12: 363-9.

11. Wesnes SL, Hunskaar S, Bo K, Rortveit G. The effect of urinary incontinence status during pregnancy and delivery mode on incontinence postpartum: a cohort study. $\mathrm{Br} \mathrm{J} \mathrm{Ob-}$ stet Gynaecol. 2009; 116(5): 700-7.

12. Viktrup L, Rortveit G, Lose G. Risk of stress urinary incontinence twelve years after the first pregnancy and delivery. Obstet Gynecol 2006; 108(2): 248-54.

13. van Brummen HJ, Bruinse HW, van de Pol G, et al. The effect of vaginal and caesarean delivery on lower urinary tract symptoms: what makes the difference? Int Uroginecol J 2007; 118(3): 133-9.

14. Bo K, Sherburn M. Evaluation of female pelvic-floor muscle function and strength. Phys Ther 2005; 85: 269-82.

15. Thakar R, Stanton S. Management of urinary incontinence in women. Br Med J 2000; 321: 1326-31.

16. Harvey MA. Pelvic floor exercises during and after pregnancy: a systematic review of their role in preventing pelvic floor dysfunction. J Obstet Gynecol Can. 2003; 25(6): 487-98.

17. Price N, Dawood R, Jackson SR. Pelvic floor exercise for urinary incontinence:a systematic literature review. Maturitas. 2010; 67(4): 309-15.

18. Freeman RM. The role of pelvic floor muscle training in urinary incontinence. BJOG, 2004; 111: 37-40.

19. Hundley AF, Wu JM, Visco AG. A comparison of perineometer to brink score for assessment of pelvic floor muscle strength. Am J Obstet Gynecol. 2005; 192(5): 1583-91.

20. Braekken IH, Majida M, Engh ME, et al. Morphological changes after pelvic floor muscle training measured by 3dimensional ultrasonography: a randomized controlled trial. Obstet Gynecol 2010, 115: 317-24.
21. Morkved S, Bo K, Schei B, Salvesen KA. Pelvic floor muscle training during pregnancy to prevent urinary incontinence: a single-blind randomized controlled trial. Obstet Gynecol 2003; 101(2): 313-9.

22. Sampselle CM, Miller JM, Mims BL, et al. Effect of pelvic muscle exercise on transient incontinence during pregnancy and after birth. Obstet Gynecol 1998; 91(3): 406-12.

23. Fritel X, Ringa V, Quiboeuf E, Fauconnier A. Female urinary incontinence, from pregnancy to menopause: a review of epidemiological and pathophysiological findings. Acta Obstet Gynecol Scand 2012; 91(8): 901-10.

24. Dinc A, Kizilkaya Beji N, Yalcin O. Effect of pelvic floor muscle exercises in the treatment of urinary incontinence during pregnancy and the postpartum period. Int Urogynecol J Pelvic Floor Dysfunct 2009; 20(10): 1223-31.

25. McKinnie V, Swift SE, Wang W, et al. The effect of pregnancy and mode of delivery on the prevalence of urinary and fecal incontinence. Am J Obstet Gynecol 2005; 193(2): 512-8.

26. Morkved S, Salvesen KA, Bo K, Eik-Nes S. Pelvic floor muscle strength and thickness in continent and incontinent nulliparous pregnant women. Int Urogynecol J Pelvic Floor Dysfunct 2004; 15: 384-90.

27. Milsom I, Ekelund P, Molander U, et al. The Influence of age, parity, oral contraception, hysterectomy and menopause on the prevalence of urinary incontinence in women. J Urol 20015; 149: 1459-62.

28. Keane DP, Sims TJ, Abrams P, Bailey AJ. Analysis of collagen status in premenopausal nulliparous women with genuine stress incontinence. BJOG, 997; 104(9): 994-8.

29. Akkus Y, Pinar G. Evaluation of the prevalence, type, severity, and risk factors of urinary incontinence and its impact on quality of life among women in Turkey. Int Urogynecol J. 2016; 27(6): 887-93.

30. Davis K, Kumar D. Pelvic floor dysfunction: a conceptual framework for collaborative patient-centred care. J Adv Nurs 2003; 43(6): 555-68.

31. Dietz HP, Lanzarone V. Levator trauma after vaginal delivery. Obstet Gynecol 2005; 106(4): 707-12.

32. Snooks SJ, Badenoch DF, Tiptaft RC, Swash M. Perineal nerve damage in genuine stress urinary incontinence. An electrophysiological study. Br J Urol. 1985; 57(4): 422-6.

33. Jundt $\mathrm{K}$, Scheer I, Schiessl B, et al. Incontinence, bladder neck mobility, and sphincter ruptures in primiparous women. Eur J Med Res 2010; 15(6): 246-52.

34. Wijma J, Weis Potters AE, de Wolf BTHM, et al. Anatomical and functional changes in the lower urinary tract during pregnancy. BJOG, 2001; 108: 726-32.

35. Subak LL, Richter HE, Hunskaar S. Obesity and Urinary incontinence: epidemiology and clinical research update. J Urol. 2009; 182: S2-7.

36. Röckner G. Urinary incontinence after perineal trauma at childbirth. Scand J Caring Sci. 1990; 4(4): 169-72.

37. Boyle R, Hay-Smith EJ, Cody JD, Mørkved S. Pelvic floor muscle training for prevention and treatment of urinary and fecalin continence in antenatal and postnatal women: a short version Cochrane review. Neurourol Urodyn. 2014; 33(3): 269-76.

38. Dumoulin C, Hay-Smith J. Pelvic floor muscle training versus no treatment, or inactive control treatments, for urinary incontinence in women. Cochrane Database of Systematic Reviews 2010, Issue 1. Art. No.: CD005654. 